\title{
LINGKUNGAN DAN MANAJEMEN PERUBAHAN DALAM ORGANISASI
}

\section{Syamsuriadi ${ }^{1}$}

\begin{abstract}
Every organization in this modern era experiences challenges of change due to the uncertainty of the organization's environment. In the view of an open system, the organizational environment is described as everything that is around the organization that may influence and be influenced by the organization. Organizations cannot live without the environment, because both are inseparable entities. Thus changes in the environment must be followed by appropriate adjustment steps by the organization in order to maintain its effectiveness. One way to make adjustments appropriately is it requires management with planned management of change. A planned change process will be able to minimize the risks that will be caused. Whereas the unplanned process of change will have an adverse impact on the life of the organization. Therefore, in managing change it is necessary to apply various approaches, and change management models, so that organizations are able to lead strategic changes.
\end{abstract}

Keywords: Environment, management of change, organization.

\section{PENDAHULUAN}

Semua organisasi pada era modern ini mengalami tantangan perubahan karena adanya ketidakpastian lingkungan. Lingkungan organisasi adalah mencakup seluruh elemen diluar batas yang memiliki potensi untuk memengaruhi organisasi. ${ }^{2}$ Ada organisasi yang menghadapi lingkungan stabil atau kurang begejolak dan ada pula organisasi yang menghadapi lingkungan yang sangat dinamis. Organisasi yang menghadapi lingkungan yang stabil berarti pada lingkungan tersebut belum terdapat pesaing baru dengan gebrakan teknologi baru dan hanya sedikit kekuatan dari kelompok yang bisa memengaruhi organisasi. Kategori organisasi yang berada pada lingkungan ini biasanya menerapkan teknologi yang unik dan mampu mendeferensiasi diri ditengah persaingan terutama dalam menghasilkan produk dan layanan konsumen

Sedangkan pada organisasi yang menghadapi lingkungan yang dinamis berarti pada lingkungan tersebut, telah terjadi turbulensi yang sangat sulit diprediksi oleh para manajer, karena telah terdapat pesaing baru yang melakukan dobrakan teknologi dalam menghasilkan produk dan pemberian layanan kepada konsumen. Penggunaan teknologi inilah yang mendorong perubahan perilaku konsumen dan harapan pelanggan, karena saat

\footnotetext{
${ }^{1}$ Manajemen Pendidikan Islam Institut Agama Islam Negeri (IAIN) Bone.

${ }^{2}$ Richard L. Daft, Manajemen, (Edisi 6, Jakarta: Salemba Empat, 2007), h.107.
} 
ini konsumen semakin tinggi tingkat pendidikannya dan semakin banyak menerima informasi. Akibatnya, harapan konsumen terhadap pelayanan yang mereka inginkan semakin meningkat dan semakin memilikibanyak pilihan dan tidak dapat didikte oleh produsen. ${ }^{3}$ Begitu pula dengan adanya perubahan peraturan pemerintah dan bertambahnya kelompok yang berpengaruh dimasyarakat yang semakin tercerahkan dengan persoalan etikal.

Lingkungan organisasi yang terus bergejolak akan memaksa para top manajer dan seluruh elemen organisasi untuk mengadakan penyesuain. Penyesuain yang dilakukan harus memperhatikan secara cermat keadaan lingkungan sehingga organisasi itu tetap berada dalam keadaan yang efektif. Dalam pengertian sistem terbuka organisasi dipandang sebagai pengembang mekanisme pemantauan dan umpan balik untuk mengidentifikasi dan mengikuti lingkungan mereka, menginderai perubahan dalam lingkungan tersebut dan membuat penyesuaian yang tepat jika dibutuhkan. ${ }^{4}$ Oleh karena itu, dalam mempertahankan keefektifannya maka organisasi harus mampu melakukan perubahan sesuai dengan kondisi yang dihadapi.

Secara umum perubahan dalam organisasi terbagi atas dua yaitu perubahan yang terencana dan perubahan yang tidak direncanakan. Perubahan yang direncanakan menurut Robbins, sebagaimana dikutif Wibowo, adalah aktivitas perubahan yang disengaja dan berorientasi pada tujuan. ${ }^{5}$ Selanjutnya Perubahan yang tidak direncanakan menurut Greenberg dan Baron sebagaimana dikutif oleh Wibowo, merupakan pergeseran aktivitas organizational karena adanya kekuatan yang sifatnya eksternal, diluar kendali organisasi. ${ }^{6}$ Berdasarkan pandangan ahli tersebut maka dapat dipahami bahwa perubahan yang terencana merupakan sebuah reaksi langsung dari hasil analisis mengenai keadaan aktual yang dialami organisasi dan keadaan yang akan dicapai (tujuan). Sedangkan perubahan yang tidak direncanakan adalah suatu keadaan dimana perubahan terjadi secara acak dan bersifat spontanitas yang pada akhirnya akan bersifat destruktif.

Salah satu cara untuk mengadakan penyesuaian dengan tepat maka dibutuhkan pengelolaan dengan manajemen transformasi yang terencana. Proses transformasi yang

3 Freddy Rangkuty, Customer Care Excellence: Meningkatkan Kinerja Perusahaan melalui Pelayanan Prima, (Jakarta; Gramedia Pustaka Utama, 2016), h. 24.

${ }^{4}$ Stephen P Robbins, Teori Organisasi Struktur, Desain \& Aplikasi, alih bahasa Jusuf Udaya (edisi 3, Jakarta: Arcan, 1994), h. 225.

${ }^{5}$ Wibowo, Manajemen Perubahan, (Edisi ketiga,Cet. 5, Jakarta:Rajawali Press, 2016), h.117.

${ }^{6}$ Wibowo, Manajemen Perubahan,h.118. 
terencana akan akan mampu mengambil langkah yang strategis dengan meminimalisir resiko yang akan ditimbulkan. Sedangkan proses perubahan yang tidak terencana akan membawa dampak yang kurang menguntungkan bagi organisasi. Oleh karena itu, langkah implementasi manajemen perubahan dan inovasi menjadi langkah strategis dalam mengadakan penyesuaian yang diharapkan.

\section{PEMBAHASAN}

\section{Konsep Lingkungan Organisasi}

Lingkungan adalah apa saja yang berada diluar batas organisasi. ${ }^{7}$ Dalam persfektif organisasi sebagai sistem terbuka menurut pandangan Scott, yang dikutif oleh Rahayu, lingkungan organisasi digambarkan sebagai keseluruhan yang ada disekitar organisasi yang dapat mempengaruhi dan dipengaruhi oleh organisasi. Sistem organisasi tidak mungkin dapat hidup tanpa lingkungan organisasi, dengan demikian perubahan lingkungan sangat berpengaruh terhadap kehidupan sistem organisasi. Scott menggambarkan 4 (empat) level lingkungan organisasi, yaitu 1) Organizational sets, meliputi domain/wilayah organisasi, produk atau layanan yang disediakan, konsumen yang dilayani dan pemasok bahan pada sisi input. Pada level ini mencakup elemen konsumen, supplier dan pesaing. 2) organizational population, mencakup turunan atau perkembangan organisasi sejenis, misalnya organisasi pendidikan, ada pendidikan dasar, menengah dan tinggi. 3) Areal organizational fields, yakni terkait dengan hubungan-hubungan dan interaksi antar anggota organisasi atau para karyawannya, termasuk dalam suatu area geografis tertentu dimana organisasi berdomisili dan memiliki jaringan kerja. 4) Fungsional organizational fields, yakni merupakan pemikiran yang mengkaitkan lingkungan dengan berbasis organisasi sebagai sebuah fungsi, ketimbang hanya melihat lingkungan secara geografi semata. ${ }^{8}$ Pandangan ini menggambarkan bahwa antara organisasi dan lingkungan tidak dapat dipisahkan kerena menjadi sebuah sistem dan merupakan satu kesatuan yang saling berpengaruh dan saling melengkapi.

Selanjutnya menurut Daft, lingkungan organisasi terbagi atas dua yaitu lingkungan eksternal dan lingkungan internal. Lingkungan eksternal dapat pula dibagi menjadi dua yaitu lingkungan umum dan lingkungan tugas. Lingkungan umum merupakan lapisan

\footnotetext{
${ }^{7}$ Stephen P. Robbins, Teori Organisasi Struktur, Desain dan Aplikasi, h.226.

${ }^{8}$ Amy Y.S. Rahayu, Manajemen Perubahan dan Inovasi, (Jakarta:UI Press, 2013), h.56-57.
} 
eksternal yang dapat mempengaruhi organisasi secara tidak langsung atau relevansinya tidak begitu jelas. Seperti faktor internasional, ekonomi, sosial, demografi, dan politik. Sedangkan lingkungan tugas lebih dekat dengan organisasi dan dan meliputi sektor-sektor yang melakukan transaksi harian dengan organisasi dan berpengaruh secara langsung terhadap operasi dasar dan kinerjanya. Contohnya para pesaing, para pemasok dan pelanggang. Selanjutnya lingkungan internal adalah mencakup seluruh elemen yang berada dalam organisasi, yang terdiri atas karyawan yang masih bekerja, manajemen, dan budaya organisasi, ${ }^{9}$

Berdasarkan pandangan tersebut, bahwa lingkungan yang paling berpengaruh secara langsung adalah lingkungan tugas karena meliputi sektor yang melakukan transaksi dengan organisasi seperti pesaing, pemasok dan pelanggan. Jika pesaing lebih agresif dan lebih tanggap terhadap kebutuhan pasar, kemudian pemasok menahan atau menaikkan harga bahan baku, ditambah lagi dengan selera dan preferensi pelanggan yang berubahubah. Hal ini akan lebih rumit jika kondisi lingkungan umum juga mengalami gejolak seperti keadaan internasional, krisis ekonomi, perubahan social dan budaya, demografi dan keadaan politik yang tidak menentu, meskipun tidak berpengaruh secara langsung akan tetapi dia akan memberikan pengaruh. Gambaran lingkungan ini sudah dipastikan akan menjadi kekuatan yang memaksa organisasi untuk melakukan perubahan karena berhadapan dengan ketidakpastian lingkungan.

\section{Sintesa Ketidakpastian Lingkungan Organisasi}

Menurut Ford sebagaimana dikutif oleh Robbins, bahwa terdapat tiga dimensi kunci yang terdapat pada setiap lingkungan organisasi, yang dijadikan sebagai sintesa dari kebanyakan literature. Ketiga dimensi itu adalah capacity (kapasitas), votality (mudah menguap), dan complexity (kompleksitas). Kemudian Robbins menjabarkan sebagai berikut: ${ }^{10}$

a. Kapasitas lingkungan merujuk pada tingkatan sejauh mana ia dapat mendukung pertumbuhan. Lingkungan kaya dan tumbuh akan menghasilkan sumber yang berlebihan yang dapat menyangga organisasi sewaktu terjadinya kelangkaan relative. Kapasitas yang berlebihan, misalnya memberi kesempatan bagi

\footnotetext{
${ }^{9}$ Richard L. Daft, Manajemen, h.107.

${ }^{10}$ Stephen P. Robbins, Teori Organisasi Struktur, Desain dan Aplikasi,h.239.
} 
sebuah organisasi untuk membuat kesalahan. Sedangkan kapasitas yang langka tidak demikian.

b. Votaliti merupakan tingkat ketakstabilan pada sebuah lingkungan. Hal ini gambarkan sebagai tingkat perubahan yang tidak dapat diprediksi, ini berarti bahwa lingkungan tersebut adalah dinamis. Kejadian inilah yang akan meyulitkan manajemen untuk meramalkan secara tepat kemungkinan yang diasosiasikan dengan berbagai alternatif keputusan. Sementara pada sisi lain terdapat lingkungan yang stabil.

c. Kompleksitas, artinya tingkat dari heterogenitas dan konsentrasi diantara elemen lingkungan. Lingkungan yangsederhana adalah homogen dan terkonsentrasi. Hal ini dapat digambarkan pada industry tembakau karena pelakunya sangat sedikit, sehingga mudah mengawasi persaingan secara ketat.Sebaliknya lingkungan yang dicirikan oleh heterogenitas dan penyebaran disebut kompleks. Contoh bisnis pada perangkat lunak komputer yang setiap hari muncul pesaing baru yang harus dihadapi.

Berdasarkan uraian tersebut diatas, maka dapat digambarkan bahwa organisasi yang menjalankan kegiatan pada lingkungan yang mengalami kelangkaan relatif, dinamis dan susah diprediksi, dan sangat kompleks, maka mengalami derajat tingkat ketidakpastian yang sangat tinggi. Dengan demikian akan menyulitkan bagi manajer dan seluruh elemen organisasi dalam menentukan altertif yang tepat. Sedangkan pada lingkungan stabil, dan sederhana justru memudahkan dalam menentukan penyesuaian dan perubahan yang tepat.

\section{Konsep Perubahan Organisasi dan Manajemen Perubahan}

Konsep perubahan menurut Caiden sebagaimana dikutif Rahayu, menggaris bawahi konsep perubahan sebagai sesuatu yang tidak beraturan, antara lain bersifat otomatis, otonom, dan tidak dapat diramalkan (unforeseen), tidak diketahui kapan berakhirnya, bersifat universal, tanpa nama, bahkan tidak dapat dimengerti. Konsep ini memandang perubahan secara alami. ${ }^{11} \quad$ Selanjutnya konsep perubahan yang lebih kompleks dikemukakan oleh Pole Van de Van yang juga dikutif oleh Rahayu, mengatakan bahwa perubahan dapat mengambil berbagai bentuk, dapat terencana dan tak terencana, inkremental maupun radikal, berulang maupun tak terduga. ${ }^{12}$ Konsep perubahan organisasi

${ }^{11}$ Amy Y.S Rahayu, Manajemen Perubahan, h.2.

${ }^{12}$ Amy Y.S. Rahayu, Manajemen perubahan, h.3. 
dapat memiliki berbagai bentuk baik terencana atau tidak terencana, perbaikan secara bertahap, atau yang bersifat evolusioner dan dapat berulang dan tidak dapat diduga.

Perubahan organisasi adalah proses melalui mana organisasi bergerak dari situasi saat ini kesituasi yang diinginkan yakni masa depan yang lebih baik dan meningkat. Tujuan dari perubahan yang direncanakan adalah untuk menjamin organisasi agar dapat menemukan suatu cara yang lebih baik dalam menggunakan sumber daya dan mengoptimalkan kapabilitasnya. ${ }^{13}$

Perubahan yang direncanakan merupakan sebuah reaksi yang bersifat langsung dalam memahami sumber masalah yang membutuhkan perubahan.

Selanjutnya menurut Brief dan Guzzo sebagaimana dikutif Batemen dan Snell, bahwa tidak ada metode "peluru perak" atau usaha satu kali yang langsung sukses dalam mengubah organisasi. Usaha satu kali langsung sukses jarang mencapai target yang menantang. Biasanya banyak hal yang memerlukan perhatian yang simultan dan setiap perubahan tunggal dan kecil akan diserap oleh budaya dan kemudian menghilang. perubahan organisasi total, meliputi memperkenalkan dan mempertahankan beragam kebijakan, praktik dan prosedur dalam beragam unit dan tingkatan. ${ }^{14}$

Manajemen perubahan menurut Potts dan LeMarsh sebagaimana dikutif Wibowo, adalah suatu proses secara sistematis dalam menerapkan pengetahuan, sarana dan sumber daya yang diperlukan untuk memengaruhi perubahan pada orang yang akan terkena dampak dari proses tersebut. ${ }^{15}$ Berdasarkan pandangan ini menggambarkan bahwa manajemen perubahan berupaya dalam memberikan jalan keluar dalam setiap kegiatan organisasi dengan cara memanfaatkan pengetahuan dan sumber daya melalui sebuah proses yang sistematis untuk memanage perubahan, terutama yang menjadi kelompok sasaran.

\section{Pendekatan Manajemen Perubahan}

Terdapat dua pendekatan untuk manajemen perubahan, yaitu planned change (perubahan terencana) dan emergent change (perubahan darurat). Penggunaan pendekatan

\footnotetext{
${ }^{13}$ Amy Y.S. Rahayu, Manajemen Perubahan, h.7.

14 Thomas S.Bateman dan Scott A. Snell, Manajemen Kepemimpinan dan Kerjasama dalam Dunia yang Kompetitif (Jakarta; Salemba Empat, 2014), h.359.

${ }^{15}$ Wibowo, Manajemen, h.241.
} 
ini tergantung pada kondisi yang dihadapi. Pendekatan tersebut dapat diuraikan sebagai berikut: ${ }^{16}$

a. Planned Change (Perubahan Terencana)

Bullock dan Batten sebagaimana dikutif Wibowo mengemukakan bahwa untuk melakukan perubahan terencana perlu dilakukan empat fase tindakan yaitu sebagai berikut

1) Eksploration phase (fase eksplorasi)

Dalam tahap iniorganisasi menggali dan memutuskan apakah dengan membuat perubahan spesifik dan operasi, dan jika demikian, mempunyai komitmen terhadap sumber daya untuk merencanakan perubahan. Kegiatan pada fase ini menyangkut kepedulian dan perlunya perubahan, mencari bantuan eksternal untuk membantu dengan merencanakan dan mengimplementasikan perubahan dan melakukan kontrak dengan konsultan mengenai tanggung jawab masing-masing pihak.

2) Planning phase (fase perencanaan)

Menyangkut pemahaman masalah dan kepentingan organisasi. proses perubahan menyangkut pengumpulan informasi dengan maksud menciptakan diagnosis yang tepat tentang masalahnya, menciptakan tujuan perubahan dan mendesain tindakan yang tepat untuk mencapai tujuan tersebut; dan membujuk pengambil keputusan kunci mencapai tujuan tersebut dan mendukung perubahan yang diusulkan.

3) Action plan (fase tindakan)

Pada tahap ini organisasi mengimplementasikan perubahan yang ditarik dari perencanaan. Proses perubahan menyangkut desain untuk menggerakkan organisasi dari current state (keadaan sekarang) ke future state (keadaan yang akan datang). yang diharapkan, dan termasuk menciptakan pengaturan yang tepat untuk mengelola proses perubahan dan mendapatkan dukungan untuk tindakan yang dilakukan; dan mengevaluasi kegiatan implementasi dan mengumpan

${ }^{16}$ Wibowo, Manajemen, h. 246. 
hasil, sehingga setiap penyesuaian dan perbaikan yang perlu dapat dilakukan

4) Integration phase (fase integrasi)

Tahapan ini dimulai begitu perubahan telah dengan sukses di implementasikan. Hal ini berkaitan dengan mengonsulidasi dan menstabilisasi perubahan sehingga sehingga mereka menjadi bagian organisasi normal, operasi sehari-hari berjalan dan tidak memerlukan pengaturan khusus atau mendoron, memelihara mereka. Proses ini menyangkut penguatan prilaku baru melalui umpan balik dan sistem penghargaan dan secara bertahap menurunkan kepercayaan pada konsultan;dan melatih manajer dan pekerkja untuk memonitor perubahan secara konstan dan melakukan perbaikan terhadapnya.

b. Emergent Approach (Pendekatan Darurat)

Emergent Approach memberikan arahan dengan melakukan penekanan pada lima gambaran organisasi yang dapat mengembangkan atau menghalangi keberhasilan perubahan, yaitu sebagai berikut:

1) Organizational structure (stuktur organisasi)

Organizational structure adalah perubahan struktural menuju pada organisasi yang lebih banyak delegasi, yang berarti hierakhi datar, pada posisi yang sangat unggul untuk bergerak daripada yang mempunyai resistensi terhadap perubahan besar. Aspek yang berkembang adalah dengan adanya gerakan menciptakan organisasi yang berpusat pada pelanggan, tannggap terhadap pasar yang berbeda fungsi. Tanggapan pelanggan menempatkan tekanan lebih besar pada proses horizontal yang efektif dan mewujudkan konsep bahwa setiap orang adalah pelanggan.

2) Organizational culture (budaya organisasi)

Organizational culture adalah suatu upaya untuk memengaruhi perubahan dalam suatu organisasi sekedar dengan berusaha mengubah budayanya mengasumsikan bahwa terdapat hubungan linear yang tidak beralasan antara budaya organisasi dengan kinerja.

3) Organizational learning (organisasi pembelajaran) 
Pembelajaran memainkan peran kunci dalam menyiapkan orang untuk bersedia melakukan perubahan, atau membiarkan mereka menghalangi perubahn. Keinginan untuk berubah sering hanya bersifat membersihkan diri dari perasaan karena tidak ada pilihan lain. Oleh karena itu, perubahan dapat turun dengan cepat dengan membuat krisis mendatang nyata bagi setiap orang dalam organisasi atau mendorong ketidakpuasan dengan sistem dan prosedur sekarang.

4) Managerial behavior (perilaku manajerial)

Pandangan trdisional organisasi melihat manajer sebagai mengarahkan staff, sumber daya dan informasi. Akan tetapi, pendekatan emergent change memerlukan perubahan radikal dalam prilaku manajer. Manajer diharapkan bekerja sebagai pemimpin, fasilitator dan pelatih melalui kemampuan meredam hambatan hierarki, fungsi dan organizational, dapat membawa bersama dan memotivasi tim dan kelompok untuk memgidentifikasi kebutuhan dan mencapai perubahan.

5) Power and politics (Kekuasaan dan politik)

Meskipun advokasi terhadap emergent change cenderung melihat kekuasaan dan politik dari perspektif yang berbeda, mereka semua mengenal arti pentingnya perubahan yang harus dikelola jika perubahan ingin menjadi efektif. ${ }^{17}$

\section{Model Perubahan}

Terdapat beberapa model perubahan antara lain model perubahan Lewin, model action research, model Ackerman, dan model positif. Berikut ini akan dipaparkan sebagai berikut:

a. Model Perubahan Lewin

Salah satu model fundamental dari perubahan terencana dicetuskan oleh Kurt Lewin yang dikutif oleh Cummings dan Worley dan selanjutnya dikutif oleh Rahayu. Lewin melihat perubahan sebagai modifikasi dari kekuatan- kekuatan yang membuat prilaku sistem tetap stabil. Serangkaian perilaku tertentu pada suatu waktu adalah hasil dari dua kelompok kekuatan yakni kekuatan yang berjuang untuk mempertahankan status quo

\footnotetext{
${ }^{17}$ Wibowo, Manajemen, h.246-247.
} 
dan kekuatan yang mendorong perubahan. Ketika kedua kekuatan tersebut seimbang, Lewin menyebut prilaku yang ada sebagai keadaan "quasi-stationary equilibrium”. Untuk mengubah keadaan tersebut, kita dapat meningkatkan kekuatan yang mendorong perubahan, menurunkan kekuatan yang mempertahankan kondisi yang ada atau menggunakan kombinasi dari keduanya. Lewin menganjurkan bahwa memodifikasi kekuatan yamng mempertahankan status quo menghasilkan lebih sedikit ketegangan dan reistensi dibandingkan meningkatkan kekuatan untuk perubahan, sehingga merupakan strategi perubahan yang lebih efektif. ${ }^{18}$

Selanjutnya lewin mengetengahkan bahwa proses perubahan melalui tiga langkah sebagai berikut:

1) Unfreezing

Kemampuan atau status quo biasanya ibarat sesuatu yang sudah membeku dan perlu waktu atau cara tertentu mencairkan kebekeuan tersebut. Prilaku yang masih mempertahankan kondisi lama harus dicairkan melalui pendekatan-pendekatan yang tepat, hingga perubahan dapat diterima. Langkah ini analog dengan penguasaan situasi dimana perubahan terencana harus dimulai dengan mengurangi kekuatan-kekuatan yang mempertahankan prilaku yang lama. Unfreezing, kadang dicapai melalui suatu proses "psikological disconfirmation" dengan menunjukkan informasi mengenai perbedaan antara prilaku yang diharapkan dengan prilaku yang dijalankan, diharapkan para anggota dapat termotivasi untuk terlibat dalam kegiatan perubahan

2) Moving

Langkah ini menggeser perilaku organisasi, departemen, atau individu pada level yang baru, termasuk intervensi di dalam struktur untuk membangun prilaku, nilai, dan sikap baru melalui perubahan pada struktur dan proses organisasi

3) Refrezing

Langkah ini menstabilkan organisasi pada kondisi ekuilibrium baru. Langkah ini sering dicapai dengan penggunaan mekanisme pendukung yang menguatkan kondisi baru organisasi, misalnya budaya, norma, kebijakan, dan struktur organisasi. ${ }^{19}$

${ }^{18}$ Amy Y.S. Rahayu, Manajemen Perubahan, h.29-30.

${ }^{19}$ Amy Y.S. Rahayu, Manajemen Perubahan, h. 3. 
b. Model Action Research

Model ini fokus pada perubahan terencana sebagai proses siklus, dimana riset awal mengenai oeganisasi memberikan informasi untuk mengarahkan tindakan selanjutnya. Kemudian hasil dari tindakan dinilai untuk memberikan informasi lebih lanjut untuk membimbing tindakan selanjutnya. Siklus riset dan tindakan yang berulang ini melibatkan kolaborasi yang cukup besar antara anggota organisasi dan praktisi OD. Model ini menekankan pada pengumpulan data dan diagnosis sebelum perencanaan tindakan dan implementasinya.

Delapan langkah dalam model action research adalah:

1) Identifikasi masalah

Tahapan ini biasanya dimulai ketika eksekutif kunci dalam organisasi atau seseorang dengan kekuatan dan pengaruh merasa bahwa organisasi memiliki satu atau permasalahan yang mungkin dapat dipecahkan dengan bantuan praktisi Organizational Development (OD)

2) Konsultasi dengan ahli ilmu prilaku

Selama pertemuan awal, praktisi OD dank lien saling menilai satu sama lain. Praktisi memiliki teori perkembangan normative dan kerangka referensi sendiri, dan ia harus sadar akan asumsi-asumsi dan nilai-nilai tersebut. Membagi hal-hal tersebut dengan klien sejak awal membangun atmosfir keterbukaan dan kolaborasi.

3) Pengumpulan data dan diagnosis pendahuluan

Langkah ini biasanya diselesaikan oleh praktiktisi OD, seringkali bersama anggota organisasi. Hal ini termasuk mengumpulkan informasi yang sesuai dan menganilisisnya untuk mengetahui penyebab dari permasalahan organisasi. Empat metode dasar mengumpulkan data adalah wawancara, observasi proses, kuisioner, data kinerja organisasi. Pendekatan untuk diagnosis dimulai dengan observasi, kemudian wawancara setengah terstruktur, dan diakhiri dengan kuisioner untuk mengukur secara tepat permasalahan yang diidentifikasikan dengan langkah langkah sebelumnya. Ketika mengumpulkan data praktisi OD dapat memengaruhi anggota organisasi. Dalam OD tiap tindakan praktisi OD dapat dipandang sebagai intervensi yang akan mempunyai efek pada organisasi.

4) Umpan balik pada kelompok atau klien kunci 
Karena action research adalah aktivitas kolaboratif data diagnostic disampaikan kembali pada klien. Langkah ini dimana organisasi diberi informasi yang telah dikumpulkan oleh praktisi OD, memahami organisasi memahami kekuatan dan kelemahan mereka melalui suatu studi. Jadi konsultan memberikan data dan informasi yang berguna dan relevan, namun konsultan juga dapat menahan beberapa informasi demi melindungi privasi dan etik, serta atas penilaian bahwa klien mungkin tidak siap menerima informasi, atau dengan informasi tersebut mmembuat klien aklan menjadi semakin defensive.

5) Diagnosis bersama terhadap permasalahan

Pada tahap ini anggota mendiskusikan feedback dan mengeksplorasi bersama praktisi OD apakah mereka ingin mengidentifikasikan masalah Ada hubungan yang erat antara pengumpulan data, umpan balik, dan diagnosis, karena konsultan meringkas data dasar dari anggota organisasi klien menyampaikan data kepada mereka untuk validasi dan diagnosis lebih lanjut.. Hal yang penting menuurut Schein adalah pada proses ini, hubungan antara organisasi klien dan konsultan/praktisi bukanlah seperti hubungan antara dokter dan pasien, dimana konsultan masuk, membuat diagnosisi dan memberikan solusi. Hubungan yang kondusif antara klien dan konsultan akan menyebabkan akan adanya kesalahan diagnosis atau jarak dalam komunikasi yang membuat organisasi tidak mau mempercayai diagnosis atau menerima solusi yang disarankan konsultan.

6) Perencanaan tindakan bersama

Praktisi OD dan organisasi bersama-sama menyetujui tindakan yang akan diambil. Ini merupakan awal dari proses moving dimana organisasi memutuskan cara terbaik untuk mencapai quastationary equilibrium. Pada tahap ini tindakan spesifik yang diambil tergantung pada budaya, teknologi, dan lingkungan organisasi, diagnosis permasalahn, serta waktu dan biaya dari intervensi.

7) Tindakan

Pada tahap ini meliputi perubahan actual dari suatu kondisi ke kondisi lain. Lankah inimencakup penerapan metode dan prosedur baru, reorganisasi struktur dan desain kerja, serta perubahan prilaku.

8) Pengumpulan data setelah tindakan 
Model action research adalah proses siklus, data harus dikumpulkan setelah tindakan dilakukan untuk mengukur dan menentukan efek dari tindakan dan memnyampaikan data kepada organisasi. Langkah ini mengarah pada rediagnosis dan tindakan baru. ${ }^{20}$

c. Model Posistif

Model positif dari perubahan terencana mencakup lima fase.

1) Mengidentifikasi subjek perubahan

Fase pertama menentukan subyek perubahan. Fase ini menekankan keterlibatan anggota organisasi untuk menentukan masalah organisasi yang mereka miliki paling banyak energi untuk dihadapi. Apabila fokus pada identifikasi ini nyata dan benar-benar vital maka proses perubahan akan dilakukan.

2) Penyelidikan untuk mengumpulkan praktek terbaik

Fase ini mencakup mengumpulkan informasi meneganai apa yang terbaik dalam organisasi, apabila topiknya adalah inovasi, maka anggota membantu mengembangkan situasi dialog atau wawancara untuk mengumpulkan cerita atau ide baru yang dikembangkan dan diterapkan dalam organisasi. Wawancara dilakukan oleh anggota organisasi, mereka saling mewawancarai dan menceritakan cerita mengenai inovasi atau pengalama mereka dimana mereka terlibat didalamnya secara langsung. Cerita-cerita ini dikumpulkan untuk menghasilkan kolam informasi yang mendeskripsikan organisasi sebagai system inovatif.

3) Menemukan tema

Pada fase ini, para anggota menganalisis cerita-cerita, baik besar maupun kecil, untuk mengidentifikasikan serangkaian tema yang mewakili dimensi yang sama dari pengalaman para anggota. Sebagai cnntoh cerita tentang inovasi mungking mengandung tema tentang bagaimana manajer memberikan kebebasan untuk mengeksplorasi ide-ide baru, dukungan yang diterima anggota organisasi dari teman kerjanya, atau bagaimana kontak dengan konsumen memicu pemikiran kreatif. Tema mewakili dasar untuk bergerak dari organisasi saat ini pada organisasi yang diinginkan.

4) Membayangkan masa depan yang diinginkan

${ }^{20}$ Amy Y.S Rahayu, Manajemen Perubahan, h. 32-35. 
Anggota organisasi kemudian menganalisa tema yang diidentifikasikan, menantang status quo dan mendeskripsikan masa depan. Berdasarkan kesuksesan organisasi dimasa lalu, anggota secara kolektif menvisualisasikan masa depan organisasi dan mengembangkan "possibility proposition" pernyataan yang menjembatani best practice organisasi yang ada dengan kemungkinan ideal untuk organisasi masa depan. Proposisi-proposisi ini harus menyajikan gambaran masa depan yang menarik, provokatif dan memungkinkan. Berdasarkan kemungkinan-kemungkinan ini, anggota organisasi mengidentifikasikan stakeholders dan proses proses penting organisasi yang harus dimasukkan untuk mendukung munculnya masa depan yang dibayangkan. Visi menjadi pernyataan "bagaimana organisasi harus menjadi"

5) Mendesain dan melaksanakan

Fase terakhir ini meliputi desain dan pelaksanaan cara-cara untuk membuat masa depan. Pada fase ini berlanjut pada fase tindakan dan penilaian yang mirip dengan action research. Para anggota membuat perubahan, menilai hasilnya, membuat penyesuaian yang diperlukan, dan seterusnya seiring mereka mengerakkan organisasi pada visi dan mempertahankan 'apa yang dicapai organisasi”. kemudian proses dilanjut dengan memperbaharui pertanyaan tentang "hal yang terbaik" dalam organisasi. ${ }^{21}$

Selanjutnya pandangan lain mengenai model manajemen perubahan dikemukakan oleh Burnes sebagaimana dikutif oleh Wibowo, bahwa perubahan organizational dapat dilihat sebagai produk dari tiga proses organisasi yang bersifat interdependen, antara lain: (1) The choice process, yang berkaitan dengan sifat, lingkup dan fokus pengambilan keputusan; (2) The trajectory process, yang berhubungan dengan masa lalu organisasi dan arah masa depan dan hal tersebut terlihat seperti hasil dari visinya, maksud dan tujuan masa depan; (3) The change process, yang mencakup pendekatan pada mekanisme untuk mencapai, dari hasil perubahan.

Ketiga proses ini memiliki saling ketergantungan satu sama lain, karena proses perubahan itu sendiri merupakan bagian integral dari trajectory process dan pada gilirannya merupakan bagian vital dari the choice process. Didalam masing-masing

\footnotetext{
${ }^{21}$ Amy.Y.S Rahayu, Manajemen Perubahan, h.35-38.
} 
prosesnya terdapat sekelompok elemen, atau kekuatan, yang saling berinteraksi, berbenturan dengan dan saling memengaruhi dengan cara yang halus dan kompleks. ${ }^{22}$

Hubungan dari ketiga proses tersebut dapat digambarkan sebagai berikut:

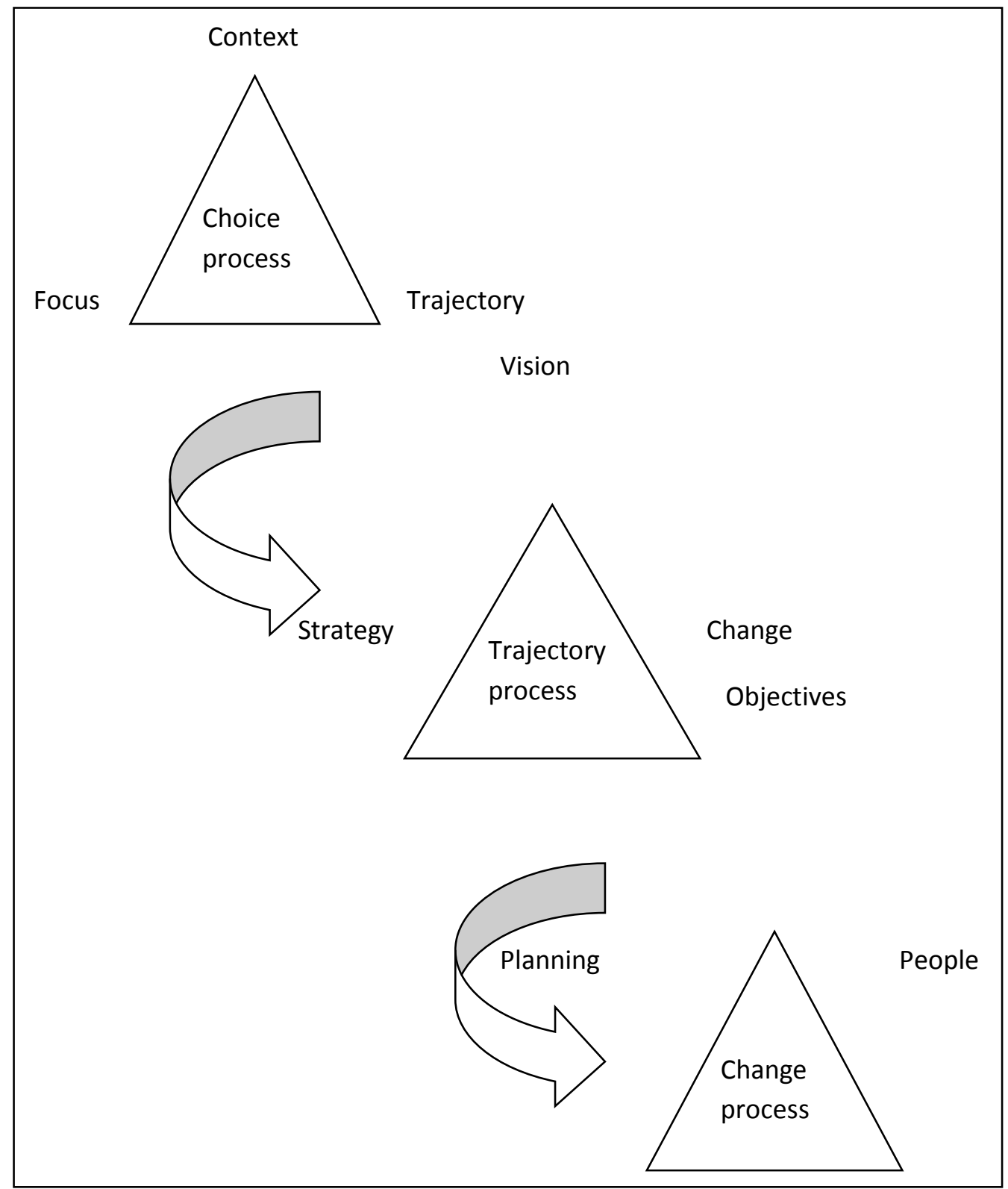

Gambar 1. Model Manajemen Perubahan Burnes. ${ }^{23}$

${ }^{22}$ Wibowo, Manajemen, h.252.

${ }^{23}$ Wibowo, Manajemen, h.253. 


\section{Menciptakan dan mimpinan perubahan}

Menurut Cristensen, sebagaiman dikutif Bateman dan Snell bahwa perubahan terjadi terus menerus dan tak terduga. Apapun keunggulan yang ada miliki dalam persaingan bergantung pada keadaan tertentu pada waktu tertentu, tetapi keadaan berubah. $^{24}$ Lingkungan semakin dinamis, karena kondisi ekonomi dunia yang tidak menentu, munculnya pesaing baru dengan berbagai dobrakan dibidang teknologi, selera pelanggan yang terus berubah yang membuat pangsa pasar semakin sulit dipertahankan.

Selanjutnya hal ini semakin dipertegas oleh Judge, Pucik dan Welbourne sebagaimana dikutif Batemen dan Snell bahwa tantangan untuk organisasi bukan hanya untuk menghasilkan produk baru yang inovatif, tetapi menyeimbangkan budaya yang inovatif dan membangun bisnis yang berkelanjutan. Untuk individu kemampuan untuk menghadapi perubahan adalah terkait dengan kinerja pekerjaan mereka. ${ }^{25}$ Manajemen kinerja menfokuskan pada apa yang diperlukan oleh organisasi, manajer dan pekerja untuk berhasil yaitu bagaimana kinerja dikelola untuk memperoleh sukses. ${ }^{26}$

Pandangan tersebut menunjukkan bahwa dalam memenangkan persaingan ditengah lingkungan yang terus berubah, sebuah organisasi tidak hanya fokus pada produknya yang inovatif akan tetapi perlu adanya penciptaan keseimbangan nilai-nilai inti yang tercermin dalam budaya yang inovatif dan dipertahankan secara konsisten dan terus melakukan pengembangan yang berkelanjutan di semua lini organisasi. Fungsi utama budaya organisasi disini adalah sebagi pembeda terhadap lingungan organisasi, sebagai perekat bagi para karyawan, mempromosikan stabilitas sistem social, sebagai mekanisme control dan integrator, membentuk prilaku bagi karyawansebagai acuan dalam menyusun perencanaan. ${ }^{27}$

Berbagai organisasi atau perusahaan kelas dunia telah mampu menciptakan produk yang bernilai tinggi dan mampu menciptakan keunggulan keuntungan jangka panjang. Mereka menghancurkan metode-metode usang, sistem dan budaya masa lalu yang menghambat keunggulan kompetitif mereka, serta menerapkan strategi yang lebih efektif dan kompetitif organisasi, srtuktur, proses dan manajemen sumber daya manusia. Hasilnya

\footnotetext{
24 Thomas S. Bateman dan Scott A. Snell, Manajemen Kepemimpinan dan Kerjasama dalam Dunia yang Kompetitif, h. 344.

${ }^{25}$ Thomas S. Bateman dan Scott A. Snell, Manajemen Kepemimpinan dan Kerjasama dalam Dunia yang Kompetitif, h. 344.

${ }^{26}$ Wibowo, Manajemen Kinerja, (Ed.3-6: Jakarta; Rajawali Pers, 2012), h.7.

${ }^{27}$ Moh. Pabundu Tika, Budaya Organisasi dan Peningkatan Kinerja Perusahaan, (cet.II; Jakarta;
} PT. Bumi Aksara,2008), h.14. 
adalah sebuah organisasi yang mampu bersaing dengan sukses pada basis global. ${ }^{28}$ Oleh karena itu, sebuah organisasi harus menjadi pioner dalam menciptakan produk unggul yang berlandaskan riset pasar, sehingga produk dan layanan yang dihasilkan sangat inovatif yang dengan sendirinya, akan mampu mempengaruhi pasar dan lingkungan global.

Menurut Black dan Gregersen, sebagaimana dikutif Wibowo, bahwa kebanyakan perubahan dilakukan dengan pendekatan "organization in" yaitu suatu pendekatan dengan cara melakukan perubahan organisasi terlebih dahulu, dan setelah itu baru diikuti perubahan individu. Pengalama justru menunjukkan kesimpulan sebaliknya. Keberhasilan perubahan dimulai dengan mengubah individu terlebih dahulu, kemudian perubahan organisasi akan mengikuti. Pendekatan “individual in" secara strategis merubah organisasi dengan terlebih dahulu mengubah individu. ${ }^{29}$

Berdasarkan pandangan tersebut menunjukkan bahwa keberhasilan suatu organisasi dalam memimpin perubahan dalam jangka panjang, sangat bergantung pada kemampuan organisasi dalam melakukan perubahan individual, dengan cara mampu menganalisis sikap mental yang dimiliki individu yang dapat menunjang perubahan yang dinginkan. Perubahan sikap dan mental individu yang tepat akan mampu membawa organisasi dalam mencapai tujuan strategisnya.

Selanjutnya menurut Black dan Gregersen sebagaimana dikutif Wibowo, bahwa terdapat tiga macam taktik dalam menentukan perubahan sebagai berikut:

a. Anticipatory change (perubahan antisipatif) Anticipatory change merupakan antisipasi terhadap kebutuhan perubahan. Dalam taktik ini, dituntut untuk melihat kedepan terlebih dahulu dengan melihat tanda-tanda yang menunjukkan perubahan. Pada pendekatan ini membantu mengenal lebih dini bahwa peta lama yang benar mungkin segera berubah menjadi salah. Atas dasar pengenalan ini, tantangan yang dihadapi adalah merumuskan terlebih dahulu bagaimana seharusnya wujud peta baru yang benar. Dengan demikian, dapat direncanakan antisipasi yang diperlukan apabila benar-benar terjadi perubahan.

b. Reactive Change (perubahan reaktif)

\footnotetext{
${ }^{28}$ Thomas S. Bateman dan Scott A. Snell, Manajemen Kepemimpinan dan Kerjasama dalam Dunia yang Kompetitif, h. 344.

${ }^{29}$ Wibowo, Manajemen, h.308.
} 
Pendekatan ini berkisar pada memberikan reaksi pada tanda yang jelas, dan memberikan tanda bahwa perubahan diperlukan. Dengan demikian perubahan reaktif merupakan reaksi karena terlihatnya tanda-tanda bahwa akan terjadi perubahan. Tanda-tanda ini dapat muncul dari pelanggan, pesaing, pemegang saham, pekerja dan stakeholder lain, yang memberikan indikasi bahwa, harus berubah sekarang, atau mungkin harus membayar harga lebih tinggi dikemudian hari apabila tidak segera melakukan reaksi.

c. Crisis Change (Perubahan krisis)

Perubahan krisis dihadapi organisasi apabila tanda-tanda untuk perubahan sudah sedemikian besar dan intensif pada suatu tingkatan yang tidak dapat dielakkan lagi. Hal tersebut terjadi karena pesaing kita telah mulai melakukan perubahan, sementara kita masih tenang-tenang saja. Apabila tanda-tanda tersebut diabaikan terlalu lama maka akan dapat dihitung konsekuensinya pada kinerja financial. Perubahan harus segera dilakukan karena kondisinya sudah kristis. $^{30}$

Ketiga taktik tersebut, masing-masing memiliki karakteristik tersendiri, seperti antisipatory change, merupakan sebuah taktik untuk mengantisipasi berbagai perubahan lebih dini, sebelum perubahan itu betul terjadi, sehingga taktik ini memberikan kesempatan kepada manajer untuk merencanakan langkah stategis dalam mengantisipasi perubahan lingkungan. Selanjutnya taktik reactif change, merupakan reaksi karena telah terlihat dengan jelas tanda-tanda perubahan akan terjadi, dan organisasi harus cepat beraksi dan harus berubah jika tidak ingin menerima resiko yang lebih besar dikemudian hari. Sedangkan perubahan krisis, merupakan semua langkah yang harus dilakukan karena lingkungan sudah sangat dnamis dimana para pesaing telah melakukan perubahan, oleh karena itu organisasi juga sudah harus melakukan perubahan karena kondisi sangat krisis.

\section{KESIMPULAN}

Semua organisasi di era modern ini mengalami tantangan perubahan karena adanya ketidakpastian lingkungan organisai. Dalam pandangan sistem terbuka, lingkungan organisasi digambarkan sebagai apa saja yang berada disekitar organisasi yang dapat mempengaruhi dan dipengaruhi oleh organisasi. Organisasi tidak mungkin dapat hidup

\footnotetext{
${ }^{30}$ Wibowo, Manajemen.....h.312-313.
} 
tanpa lingkungan organisasi, karena keduanya merupakan satu kesatuan yang tidak dapat dipisahkan. Dengan demikian perubahan lingkungan harus diikuti dengan langkah penyesuain yang tepat oleh oragnisasi agar tetap dapat mempertahankan keefektifannya. Salah satu cara untuk mengadakan penyesuaian dengan tepat maka dibutuhkan pengelolaan dengan manajemen perubahan yang terencana. Proses perubahan yang terencana akan mampu mengambil langkah yang strategis dengan meminimalisir resiko yang akan ditimbulkan. Sedangkan proses perubahan yang tidak terencana akan membawa dampak yang kurang menguntungkan bagi kehidupan organisasi. Oleh karena itu, dalam memanage perubahan perlu diterapkan berbagai pendekatan, dan model manajemen perubahan, sehingga organisasi mampu memimpin perubahan yang strategis. Dalam proses memimpin perubahan yang strategis dibutuhkan penciptaan keseimbangan nilai-nilai inti yang tercermin dalam budaya yang inovatif dan dipertahankan secara konsisten dan terus melakukan pengembangan yang berkelanjutan di semua lini organisasi.

\section{DAFTAR RUJUKAN}

Bateman, Thomas S. dan Snell, Scott A, Manajemen: Kepemimpinan dan Kerjasama dalam Dunia yang Kompetitif, Jakarta; Salemba Empat, 2014.

Daft, Richard L, Manajemen, Edisi Enam: Jakarta; Salemba Empat, 2007.

Rahayu, Amy.Y.S, Manajemen Perubahan dan Inovasi. Jakarta; Penerbit Universitas Indonesia (UI-Press), 2013.

Rangkuty, Freddy, Customer Care Excellence: Meningkatkan Kinerja Perusahaan melalui Pelayanan Prima, Jakarta; Gramedia Pustaka Utama, 2016.

Robbins, Stephen P, Teori Organisasi: Struktur, Desain, dan Aplikasi. Alih bahasa, Yusuf Udaya,, Jakarta; Arcan, 1994.

Tika, Pabundu Moh, Budaya Organisasi dan Peningkatan Kinerja Perusahaan, cet.II;

Jakarta; PT. Bumi Aksara, 2008.

Wibowo, Manajemen Perubahan. Ed.3.Cet.5;Jakarta; Rajawali Pers, 2016.

, Manajemen Kinerja, Ed.3-6: Jakarta; Rajawali Pers, 2012. 